\section{答 林}

水による膨潤のグラフは非常に桩大されているた め、そのように見えるのではないかと思われる。不 吸水があっても形態的には殆んど変化がないという 場合も当然考光られ。

\section{賈問 (久留米) 小林}

(1)レジン霜の唇面と床面との各種溶媒による影響 (2)乳酸に対する変化

\section{答 住田}

(1)との際実験に使つた各種溶媒についてはモノマー 以外相違はないと思われるが、モノマーによって は切端用とデンチン用の溶解の相違が見られる。

(2)乳酸による実験を行ってないのでいえない。

\section{合釘継続遥の支台破折防止より見たる根 管型態について}

(補 雱) 吉永恒雄、川端昭一

破折の原因として、歯質の強弱、根管拡大の程度、 特に藻蝕による根管の拡大されている物は破折、脱落 し易い物である。その原因探究のために、肉溥円筒の 強度の理論、歯頸部の根管形態より晃て、その根管の 形態を從来の川型より漂管型及び逆丁字型にしたもの についての実験をアムスラー (Amsler)の Testing machine について行つた。赛験材料はレジンなび に天然函を同一条件で使用して。光弾性実験の応力試 験は後日の機会に発表する。

\section{一家系に見られた小曰咬合中央結節 $\sigma-$ 例$$
\text { (口 外) 高 山宗 雄 }
$$ \\ 唇一顎一口蓋裂並びに顏裂患者の統計的 観察$$
\text { (口: 外) 西正勝 }
$$

私は過去12年間に九州歯科大学口腔外科学教室で取 扱つた唇、頢、口㥺ならびに顔裂㭧者640例を対象と して男女比率、単純性と複雑性の頻度、各破裂形の相 関連して現われる頻度ならびに左存別頻度、他部先天 性畸形の合併例ならびに取扱症例の死亡率等について 研它調査したので、その結果意報告する。

綜合的な男女比率では男性368例、女性272例で男性 そ多く発現するととを示しているが、但し軟口盖裂の みに拟ては男性より女性化多く発現している。単純 性、複雑性に分けると複雑性が高率を示した。各形破 裂を左右別にみれば、唇、顎、口瑟ならびに顔裂に和 いては総合的に左側断然多く発現している。完全、

不完全破裂分けてとの頻度觉みると唇、顎裂ともに 完全破裂の頻度が高くなつている。各形破裂が 2 種以 上相関連して現われる頻度に扣いては、唇一顎一口蓋 裂の関連で現われるものが最も多い。身体他部の先天 的略形の合併例は 9 種であつて、その中でも舌痖着が 15例で最も多い。又仮性牛陰陽性型、ボタ口氏管遺残

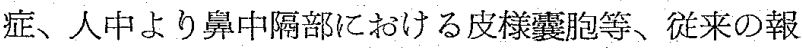
告にあまり例をみない稀有なる症例が各々 1例づつ見 られた。手術による死亡例は 2 例であって、死亡率は 著しく低い。乙の成績は我が教室に扣ける手術時期の 選択、手術及び麻酔術式、術前術後処犆等の総合的成 果によるものと思われる。

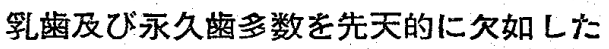
姉妹の症例

(口) 外) 竹 屋 隆 典

日常の臨床に和いて、少数の乳歯及び永久歯が先天 的に久如している例にはしばしば遭遇し、多数の報告 がなされているが、先天的に多数の永久雷が蔝列加ら 欠如している例は比輘的稀である。私は今回函の萌出 が大変少ないのでその辦断を希望して本院外来を訪れ た姉妹に扚いて、多数の先天的菌牙欠如の例に遭遇し たので報告した。

患者は16才及び10才の姉妹で姉に抽いては乳菡 2 本、永久雨27本、妹に扣いては乳曾 6 本、永久歯 32 本 の先天的欠如があつた。本症例に执いては同一家系に

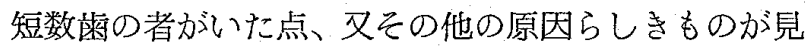
られないこと等により遗伝的な要溸怔考えられるもの である。

\section{推藍 講 實 (10分)}

白鼠の比生長汇臨する研究 医学㙛士毛利邦 雄

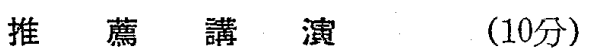

故射性燐 $\mathrm{P}^{32}$ の内部照射に関する函科学 的実験的研究 䜿㙛士 向坊 垡義

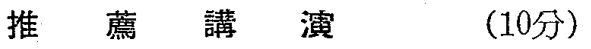
䠌牙の発育に及ぼす Cortisone の影響（欠） 医学搏士 大 神 正

推鷿 演 唃乳動物における巠蛽部の皮穊及び口腔底 諸筋の比较解剖学的研究

(医学得士) 古川 正之 犬、猫、いたら、娄ぐら、穴熊山羊、咞、鼠、兔、 